INTERNATIONAL JOURNAL OF RESEARCHES IN BIOSCIENCES, AGRICULTURE AND TECHNOLOGY (C) VISHWASHANTI MULTIPURPOSE SOCIETY (Global Peace Multipurpose Society) R. No. MH-659/13(N) www.vmsindia.org

\title{
STUDY OF SEASONAL PHYSICO-CHEMICAL AND MACROINVERTEBRATES VARIATIONS OF RIVER KOLAR AT SAONER, MAHARASHTRA
}

\author{
S. R. Verma and R. R. Kamdi \\ Anand Niketan College, Anandwan, Warora-442914 \\ sanyogitaverma15@gmail.com
}

\begin{abstract}
:
The seasonal variation of River Kolar at Saoner was studied for a period of one year. In the present study various physico-chemical parameters were analyzed for various seasons; summer, monsoon, winter from the period of August 2012 to July 2013 in surface water of river Kolar including macroinvertebrates diversity. The present study revealed that the physico-chemical parameters showed a great seasonal variation. Seventeen genera belonging to seven orders of macroinvertebrates were found which include Ephemeroptera, Diptera, Coleoptera, Hemiptera, Plecoptera, Odonata and Trichoptera indicating good quality of water. Correlation between the hydrological attributes showed good relationship and Transparency, dissolved oxygen and $\mathrm{pH}$ were found to be most important variables in shaping benthic faunal assemblage.
\end{abstract}

Keywords: Physico-chemical, Macro-invertebrates, Kolar River, Food chain, Bioindicators, Water pollution.

\section{Introduction:}

Water is the important component of all living beings. It also performs unique and indispensable activities in earth ecosystem, biosphere and biogeochemical cycles. The growth and diversity of aquatic micro fauna in river system influenced by several physico chemical and biological parameters. Water is the most basic and vital resource of our planet. According to the UN (United Nations) reports, 1978 consumable water levels are up to $2.7 \%$ of the total water content. $1 \%$ of the ground water levels are threatened either directly or indirectly by pollution. River water act as receiving end of industrial wastes residential area discharges with increase the pollution stress on these surface water bodies (Belorkar, 2010)

The extent of human activities that influence the environment particularly the freshwater has increased dramatically during the past few decades (Khanna et al., 2006). The scale of socio-economic activities, urbanizations, industrial operations and agricultural production has a widespread impact on water resources (Kurbatova, 2005). Over the last century, riverine ecosystems have suffered from intense human intervention resulting in habitat loss and degradation and as a consequence, the aquatic diversity has become the main victim particularly in rivers (Chovance, 2003). Aquatic insects have a significant role in an aquatic ecosystem, as they are the important organisms dwelling at the secondary trophic level of the ecosystem. The type and distribution of benthic invertebrates have also been widely used as an indicator of water quality and ecological disturbances. The macrozoobenthic population is very sensitive to any environmental perturbation and is highly influenced by environmental change. Distribution, density and biomass of benthic organisms depend upon the physico-chemical characteristics of the water, the nature of the sediments or substratum, biological complexes such as food, predation and other factors. The macroinvertebrate community has been considered as an indicator of stream ecology. Freshwater macrovertebrates are one of the most threatened taxonomic groups (Darwell, 2005) because of their high sensitivity to the quantitative and qualitative alteration of aquatic habits (Sarkar et al, 2006). Being an important part of food chain, today the diversity and associated habitat management is a great challenge (Dudhegaon et al., 2006). Conservation measures to mitigate the impact of the pressures have largely been slow and inadequate and as a result many of the species are declining rapidly. The present study was conducted to monitor seasonal physico-chemical variation and macrobenthic diversity of River Kolar, at Saoner, Dist. Nagpur, Maharashtra.

\section{Materials and Methods: Study area}

The Kolar River (Kolhar River) is a river of Nagpur district, Maharashtra, India, flowing southeast from above the town of Saoner to its juncture with the Kanhan River. It is in the Godavari river basin. The Kolar River forms the boundary between Saoner taluka and Ramtek taluka.

A general survey of the river was made for the study of various abiotic parameters. In view of activities of locality resides on the bank of river, one sampling station has been selected along the stretch of river in the vicinity of Saoner town. The sewage water from some parts of town is discharged in to the river at this station. 
However, the temple wastes, bathing activities and river basin agriculture are observed near the bridge on Saoner - Adasa road, located at Pahalepar area in Saoner town.

Sampling of water is proposed to carry out monthly for three different seasons, rainy, winter and summer season from August 2012 to July 2013. The acquisition of meaningful data demands correct sampling and storage procedures. The preservations and analyses of water samples was performed according to standard methods (APHA, 1998).

Macrobenthos were collected from the shallow bottom region of the river and preserved in $4 \%$ formaline. The identification of the benthic fauna samples were made with the help reference manual (Alfred et al., 1973; Tonapi, 1980; Ward and Whipple, 1959; 1992; Welch, 1948).

\section{Result and Discussion:}

The physico-chemical parameter values obtained in different seasons of River Kolar at Saoner are given in Table 1. The maximum temperature was recorded during the summer $\left(29.1^{\circ} \mathrm{C}\right)$ whereas the minimum temperature was recorded in winter $\left(21.3^{\circ} \mathrm{C}\right)$. Decreased values of temperature during winter days are due to low ambient temperature, (Gyannath et al., 2000). $\mathrm{pH}$ lies between 7.7 to 8.5 . According to the potability standards of natural water the $\mathrm{pH}$ varies usually between 7.2 and 7.6 and hence increase is noticed in the $\mathrm{pH}(\mathrm{pH}=8.5)$ which can result from the dissolution of calcium and magnesium existing from the mountain region which indicates that water is slightly alkaline in nature.

Transparency is light penetration capacity of the water. The color of water is due to concentration of suspended organic and inorganic particles. Transparency varied from maximum $108 \mathrm{~cm}$ to $78 \mathrm{~cm}$. The less transparency observed during rainy season and summer season. While during winter comparatively the water showed more transparency.

Total dissolved solids include salt and variety of organic substances, which readily dissolve in water and often impart a degree of hardness. The value of total dissolved solids ranged between maximum $316 \mathrm{mg} / 1$ to minimum $216 \mathrm{mg} / 1$. The maximum seasonal value is observed in rainy season and minimum value in winter season. Moreover the low value of total dissolved solids in summer and high in rainy season was observed by Trivedy et al. (1988).
The ionic status of water determines the conductivity. During summer and rainy days the enhanced values of conductivity may be due to presence of carbonates and bicarbonates in the water in more quantity due to pollutants. The exchange of inorganic ions by increased micro flora during the winter showed the moderate values of conductivity during the winter period.

Hydrogen ion concentration is considered as a important ecological factor, which is a result of interaction of various substances in water and in numerous biological phenomenon. According to Hutchinson (1957) nearly neutral $\mathrm{pH}$ of water is regulated by carbon dioxide and bicarbonates. The river water showed well alkaline water through the study period. $\mathrm{pH}$ of river ranges between 7.7 to 8.5 .

Total alkalinity of water is mainly due to cations of Calcium, Magnesium, Sodium and Potassium. It is also due to combined carbonate or bicarbonate or occasionally hydroxides. Seasonal analysis of water showed the higher alkalinity during the winter and summer seasons.

Total hardness in river water ranges from $128 \mathrm{mg} / 1$ to $254 \mathrm{mg} / 1$. During the summer season the higher values of hardness were observed and lower values during winter season. Ugale and Hiware (1999) have recorded the similar findings. Pratibha et al. (2005) also supports the present findings.

Dissolved oxygen is also one of the important factors of water quality, which influences the biota present inside the river water. Adebisi (1981) have reported the seasonal fluctuation of dissolved oxygen in water bodies. Similar pattern of DO observed in the present study, it decreases during the hot days of summer. DO show the inverse relationship with the temperature in river water.

Biological oxygen Demand is a direct measure of oxygen requirement and indirect measure of biodegradable organic matter. The maximum B.O.D. was $25 \mathrm{mg} / 1$ in summer and minimum $10.9 \mathrm{mg} / 1$ in winter. Similar findings were observed by Seenaya and Zafar (1979).

Chemical Oxygen Demand indicates the extent of chemical pollution mainly from industrial effluents. The C.O.D. values observed maximum in winter and minimum in rainy season. Similar findings were observed by Singh and Roy (1995).

Ammonia is present naturally in surface water and waste waters. The high values of Ammonia are a sign of pollution, Bruce (1958). 
The concentration of organic matter including the religious wastes and other proteinus matter in summer days undergoes the microbial decomposition. The enhanced rate of decomposition by microbes due to increased temperature in summer days increased the values of ammonia in river water.

In the present study, nitrate values ranged between 0.026 to $0.019 \mathrm{mg} / 1$ maximum of nitrate values were reported during rainy season and summer and minimum during winter. Gohram (1961) observed the high value of nitrate in rainy season, which is linked to heavy run-off of the organic matter from the catchments.

Phosphate concentration in river water ranged between $0.069 \mathrm{mg} / 1$ to $0.041 \mathrm{mg} / 1$. more concentration of phosphates recorded during the summer and winter season. It may be due to deposition of ashes and bones under religious activities and decomposition of organic matter in the water sediments.

Sulphate is produced by biological oxidation of sulphur content of organic matter. The sulphate value ranges between $19.80 \mathrm{mg} / 1$ to $10.9 \mathrm{mg} / 1$. According to Angadi et al. (2005) minimum concentration of sulphate was in winter and maximum in summer.

\section{Macrovertebrate diversity and their Relationship with hydrological attributes}

Benthic aquatic insects are sensitive indicators of environmental changes in streams because they express long term changes in water and habitat quality rather than instantaneous conditions (Johnson et al, 1993; Resh 1995). The total density of benthic macroinvertebrate fauna exhibited a generally increasing trend from monsoon to winter (Table
2). Macroinvertebrates were mostly contributed by the immature stages (nymphs) of aquatic insects. These nymphs belonged to the orders of Ephemeroptera (Mayflies), Plecoptera (stone flies), Trichoptera (caddis flies), Diptera, Coleoptera, Hemiptera, Odonata. A total of 7 macro invertebrates taxa including 17 genera were recorded from the River Kolar. Ephemeroptera were dominated by four genera, Coleoptera and Odonata was found to be codominant by presence of three genera, Diptera and Hemiptera have two genera and Tricoptera consist of only one genera. A thorough study reveals that maximum abundance of macroinveretebrates was found in winter and minimum in rainy season. So the sequence of abundance of macro-invertebrates in River Kolar is as follows

winter $>$ summer $>$ Monsoon

Maximum abundance of macroinvertebrates was found during winter season in the river Yamuna, which may be due to increased growth efficiency of insects during this period inaddition to hydrological attributes.

The high abundance of macroinvertebrates during winter may be explained as due to high dissolved oxygen and high transparency. The macroinvertebrate density declined in the monsoon season. The reason for this may be low dissolved oxygen content due to high turbidity which may be the cause of less penetration of light and low photosynthetic activity, thus a disturbance in food chain which results in low benthic diversity. The average macrobenthic density showed an inverse relationship with temperature but was positively correlated with the transparency.

Table 1: Physico-chemical parameters of River Kolar

\begin{tabular}{|l|l|l|l|l|}
\hline Sr. No. & Parameter & Rainy Season & Winter Season & Summer Season \\
\hline 1. & Temperature $\left({ }^{\circ} \mathrm{C}\right)$ & 25.1 & 21.3 & 29.1 \\
\hline 2. & Transparency $(\mathrm{cm})$ & 78 & 108 & 96 \\
\hline 3. & T.D.S. $(\mathrm{mg} / 1)$ & 316 & 216 & 297 \\
\hline 4. & Conductivity & 367 & 277 & 401 \\
\hline 5. & $\mathrm{pH}$ & 7.7 & 8.5 & 7.9 \\
\hline 6. & Alkalinity $(\mathrm{mg} / 1)$ & 146 & 159 & 186 \\
\hline 7. & Hardness $(\mathrm{mg} / 1)$ & 146 & 128 & 254 \\
\hline 8. & D. O. $(\mathrm{mg} / 1)$ & 8.2 & 10.1 & 5.9 \\
\hline 9. & B.O.D. $(\mathrm{mg} / 1)$ & 11.2 & 10.9 & 25 \\
\hline 10. & Ammonia(mg/1) & 0.014 & 0.011 & 0.061 \\
\hline 11. & Nitrates $(\mathrm{mg} / 1)$ & 0.026 & 0.019 & 0.022 \\
\hline 12. & Phosphates $(\mathrm{mg} / 1)$ & 0.041 & 0.064 & 0.069 \\
\hline 13. & C.O.D. & 118.1 & 148.9 & 72.6 \\
\hline 14. & Sulphate & 15.1 & 10.9 & 19.80 \\
\hline
\end{tabular}


Table 2: Seasonal Spatial Qualitative and Quantitative Distribution of Macroinvertebrates

\begin{tabular}{|l|l|l|l|}
\hline Macrobenthos & Monsoon & Winter & Summer \\
\hline Ephemeroptera & \multicolumn{5}{|l|}{} \\
\hline Ephemera & $1.25 \pm 2.50$ & $30.0 \pm 4.24$ & $7.25 \pm 7.36$ \\
\hline Leptophlebia & $6.5 \pm 11.09$ & $42.50 \pm 10.84$ & $17.5 \pm 15.35$ \\
\hline Cleon & $0.75 \pm 1.50$ & $9.75 \pm 10.50$ & $7.75 \pm 12.97$ \\
\hline Heptagenia & $6.75 \pm 8.30$ & $30.25 \pm 6.29$ & $17.25 \pm 11.14$ \\
\hline Diptera & $28.25 \pm 8.22$ & $10.75 \pm 10.78$ \\
\hline Chironomous & $8.75 \pm 6.39$ & $13.75 \pm 6.39$ & $4.50 \pm 4.43$ \\
\hline Bibiocephala & $1.25 \pm 1.89$ & $11.25 \pm 3.40$ & $2.75 \pm 3.40$ \\
\hline Coleoptera & $21.5 \pm 6.19$ & $6.25 \pm 6.13$ \\
\hline Hydraticus & $1.0 \pm 1.41$ & $13.5 \pm 4.65$ & $2.50 \pm 3.31$ \\
\hline Hydrophilus & $3.50 \pm 3.41$ & $14.25 \pm 7.32$ & $6.50 \pm 5.44$ \\
\hline Dryops & $0.75 \pm 1.50$ & $16.5 \pm 4.93$ & $3.75 \pm 3.86$ \\
\hline Hemiptera & $1.25 \pm 2.50$ & $25.75 \pm 8.99$ & $9.75 \pm 5.56$ \\
\hline Micronecta & $5.0 \pm 4.39$ & $23.75 \pm 4.78$ & $8.0 \pm 3.91$ \\
\hline Heleoceris & $5.0 \pm 5.83$ & $12.0 \pm 9.27$ & $2.0 \pm 2.82$ \\
\hline Plecoptera & $3.25 \pm 6.5$ & $5.25 \pm 5.12$ & $2.50 \pm 3.31$ \\
\hline Perla & $12.25 \pm 4.11$ & $4.75 \pm 3.77$ \\
\hline Isoperla & $28.25 \pm 6.18$ & $10.50 \pm 5.0$ \\
\hline Odonata & $0.25 \pm 0.25$ & $0.0 \pm 0.0$ & \multicolumn{5}{|l|}{} \\
\hline Matrona & $0.75 \pm 1.50$ & \multicolumn{5}{|l|}{} \\
\hline Agrion & $6.75 \pm 6.94$ & \\
\hline Corixa & Trichoptera & \multicolumn{5}{|l|}{} \\
\hline Hydrosyche & \multicolumn{5}{|l|}{} \\
\hline
\end{tabular}

\section{Conclusion:}

It may be inferred from the above discussion that the nature of the physicochemical environmental parameters dominate the river which influence the diversity of macroinvertebrates. Overall the conditions of River Kolar at Saoner are still justifiable. But proper measures should be implemented to avoid contamination, as water is used for drinking purpose. At present the river is suitable for irrigation and fishery purpose.

\section{References:}

Adebisi (1981): The physicochemical hydrobiology of a tropical river upper Ogun river Nigeria. Hydrobiol. Vol. 79(2): Pp. 157-165.

Alfred, J. R. B., Bricice, S., Issac, M. L. (1973): J. Madras. Univ. Suppl.1: 103-151.

Angadi, S. B., Shiddamallayya, N. and Patil, P. C. (2005): Limnological studies of Papanash pond, Bidar, Karnataka. J. Env. Biol. Vol. 26(2): Pp. 213-216.

APHA 20th Edition (1998): Washington: American Public Health Association.

Belorkar, A. S. (2010): Assessment of the deterioration in physicochemical and microbiological Quality of Shivnath River water in Durd in District, India. Pp.733-738.
Bruce (1958): Report on biological and chemical investigation of the waters in the Aven and Hethcata rivers. Reprinted by the pollution advisory council, Morimo department, Wellington, New Zealand.

Chovance, A., Hoffer, R. and Schiemer, F. (2003): 639-675.

Darwall, W. R. T. and Vie, J. C. (2005): Fish Manag. Ecol. Vol. 12: Pp. 287-293.

Dudhgeon, D., Arthington, A. H., Gessner, M. O. (2006): Biol Rev. Vol. 81: Pp. 163-182.

Gohram (1961): The chemical composition of some waters from Dune slacks at Sandscale, North Lancshire. J. Ecology. Vol. 49(1): Pp. 7982.

Gyananath, G., Shevnikar, S. V. and Samiuddin, S. (2000): Water quality analysis of river Godavari during "Holimela" at Nanded. Poll. Res. Vol. 19 (4) : 673.

Hutchinson, G. E. (1957): A treatise on limnology vol. II John Wiley and Sons, New York. Pp.1015.

Johnson, R. K., Wiederholm, T. and Rosenberg, D. M. (1993): In: Rosenberg D. M., Resh, V. H. (eds.) Freshwater biomonitoring and benthic macro-invertebrate. Chapman \& Hall, New York: Pp. 40-158. 
Khanna, D. R., Pathak, S. K., Bhutiani R. and Chandra, K. S. (2006): Env. Cons. J. Vol. 7(3): Pp. 79-84.

Kurbatova, S. A., IzvAkadNauk (2005): SerBiol. Vol. 1: Pp. 100-108.

Pratibha, V., Raithak and Bhuktar, A. S. (2005): Physicochemical analysis of drinking water from different areas of Aurangabad. Poll. Res. 24(3): Pp. 727-728.

Resh, V. H. (1995) In: Davis WS, Simon TP (eds) Biological assessment and criteria. Lewis, Chelsea. Pp. 167-177.

Sarkar, U. K., Pathak, A. K. and Lakra, W. S. (2008): Biodivers. Conserv. Vol. 17: Pp. 24952511.

Seenaya, G. and Zafar, A. R. (1979): An ecological study of Mir Alam Lake, Hyderabad, India. Indian. J. Biol. Vol. 11(2): Pp. 330-335.
Singh, J. P. and Roy, S. P. (1995): Limnobiotic investigation of Karwarlake, Begusarai, Bihar. Env. Eco. Vol. 13: Pp. 330-335.

Tonapi, G. T. (1980): Fresh Water Animals of India. New Delhi: Oxford and I.B.M. Publishing Company.

Trivedy, R. K., Goel, P. K., Shrotri, A. C., Khatavkar, S. D. (1988): Prospective in Aquaculture. Biol. Pp. 15-18.

Ugale, B. J. and Hiware, C. J. (1999): Limnological study of an ancient reservoir Jagtunga Samudra located at Kandhar, Dist. Nanded, Maharashtra, India. Eco. Envi and Cons. Vol. 11(3-4): Pp. 473-475.

Ward, H. B. and Whipple, G. C. (1959): Freshwater Biology, 2nd Edition, John Wiley and Sons, New York, USA.

Ward, H. B and Whipple, G. C. (1992): Freshwater biology, 2nd edn. Wiley, New York, USA. Pp. 1-1248. 